\title{
Anaplastic lymphoma kinase inhibitor-associated myositis
}

Akinori Uruha, MD, PhD, Stefan Kliesch, MD, Simone Schmid, MD, Carsten Dittmayer, MD, Hans-Hilmar Goebel, MD, Alexander Dressel, MD, Werner Stenzel, MD, and Robert Handreka, MD

Neurol Neuroimmunol Neuroinflamm 2020;7:e735. doi:10.1212/NXI.0000000000000735

Anaplastic lymphoma kinase (ALK) inhibitors have been used in patients with non-small cell lung cancer (NSCLC) harboring EML4-ALK fusion gene. ${ }^{1}$ Severe skeletal muscle adverse events of ALK inhibitors, such as muscle weakness, have seldom been reported. ${ }^{2,3}$ Herein, we describe a patient who showed a severe skeletal muscle deficit after the administration of the ALK inhibitor, alectinib, and was successfully treated by corticosteroids without withdrawal from the cancer therapy.

\section{Case report}

A 55-year-old woman was diagnosed with stage IV (cT1 cN pM1c) lung adenocarcinoma harboring EML4-ALK translocation, which was confirmed by the fluorescent in situ hybridization analysis. Metastases in brain, liver, and kidney were found at the time of primary diagnosis. She first received crizotinib for 1 month but showed resistance to it. Therefore, it was replaced by alectinib $(600 \mathrm{mg} / \mathrm{d})$ combined with whole brain radiation therapy ( $30 \mathrm{~Gy})$. The treatment led to regression of the tumors, maintaining her good general status. However, 7 months after change of the treatment, she presented slowly progressive weakness of axial and proximal muscles and mild posterior neck pain. On examination, she showed head drop and could not raise her arms above her head nor stand up from a squatting position. Neurologic examination revealed no further abnormal signs of muscle bulk, cranial nerves (in particular, no ptosis), cerebellar, sensory, and autonomic systems. Serum creatine kinase (CK) levels were elevated to $1342 \mathrm{U} / \mathrm{L}$ (normal: <171). Myositis-specific/associated autoantibodies were negative as far as tested: SRP, TIF1 $\gamma$, Mi-2, Jo-1, cN1A, RNP, Sm, Ro/SS-A, LA/SS-B, and Scl-70. Antinuclear antibodies (MPO and PR3) and paraneoplastic and myasthenic autoantibodies were also not detected: $\mathrm{Hu}, \mathrm{Yo}, \mathrm{Ri}, \mathrm{CV} 2$, amphiphysin, recoverin, SOX1, Ma2, titin, acetylcholine receptor, MuSK, VGCC ( $\mathrm{N}$ and PQ), and MAG. M protein was not detectable in her serum. Tumor enlargement or tumor marker elevation was not observed. Skeletal muscle MRI showed edematous changes in the posterior neck muscles, which were enhanced by gadolinium (figure, A-E). EMG demonstrated myopathic changes with fibrillation potentials and positive sharp waves in cervical paraspinal muscles. A repetitive nerve stimulation test was normal. There were no abnormal findings in cardiac and respiratory tests. Biopsy of left semispinalis capitis muscle was performed, revealing overt inflammatory changes with marked fibrosis (figure, F-M). Many fibers were atrophic and showed overexpression of major histocompatibility complex class I. A few necrotic fibers were observed. Inflammatory cells were diffusely present and formed several clusters consisting of predominantly CD20-positive cells. Sarcolemmal C5b-9 complement deposition on nonnecrotic fibers was scattered. Because inflammatory myopathy was shown, corticosteroid treatment was started $(150 \mathrm{mg} / \mathrm{d}[\sim 2 \mathrm{mg} / \mathrm{kg}$ body weight/day $]$ with prednisolone for 3 days, followed by $80 \mathrm{mg} / \mathrm{d}$ and gradually tapered to $7 \mathrm{mg} / \mathrm{d}$ for 2 months). The treatment was effective, leading to recovery of head drop and relief of neck pain within 2 weeks and

\author{
Correspondence \\ Dr. Stenzel \\ werner.stenzel@charite.de
}


normalization of muscle power in 4 limbs within a few weeks. Two months after the initiation of corticosteroid treatment, serum CK levels were decreased to 272-341 U/L. Eventually, under corticosteroids, the patient tolerated continuation of cancer therapy well.

\section{Ethical statement}

Informed consent was obtained from the patient. The Charité Ethics Committee (EA2/163/17) granted ethical approval.

Figure MRI and pathology of skeletal muscles
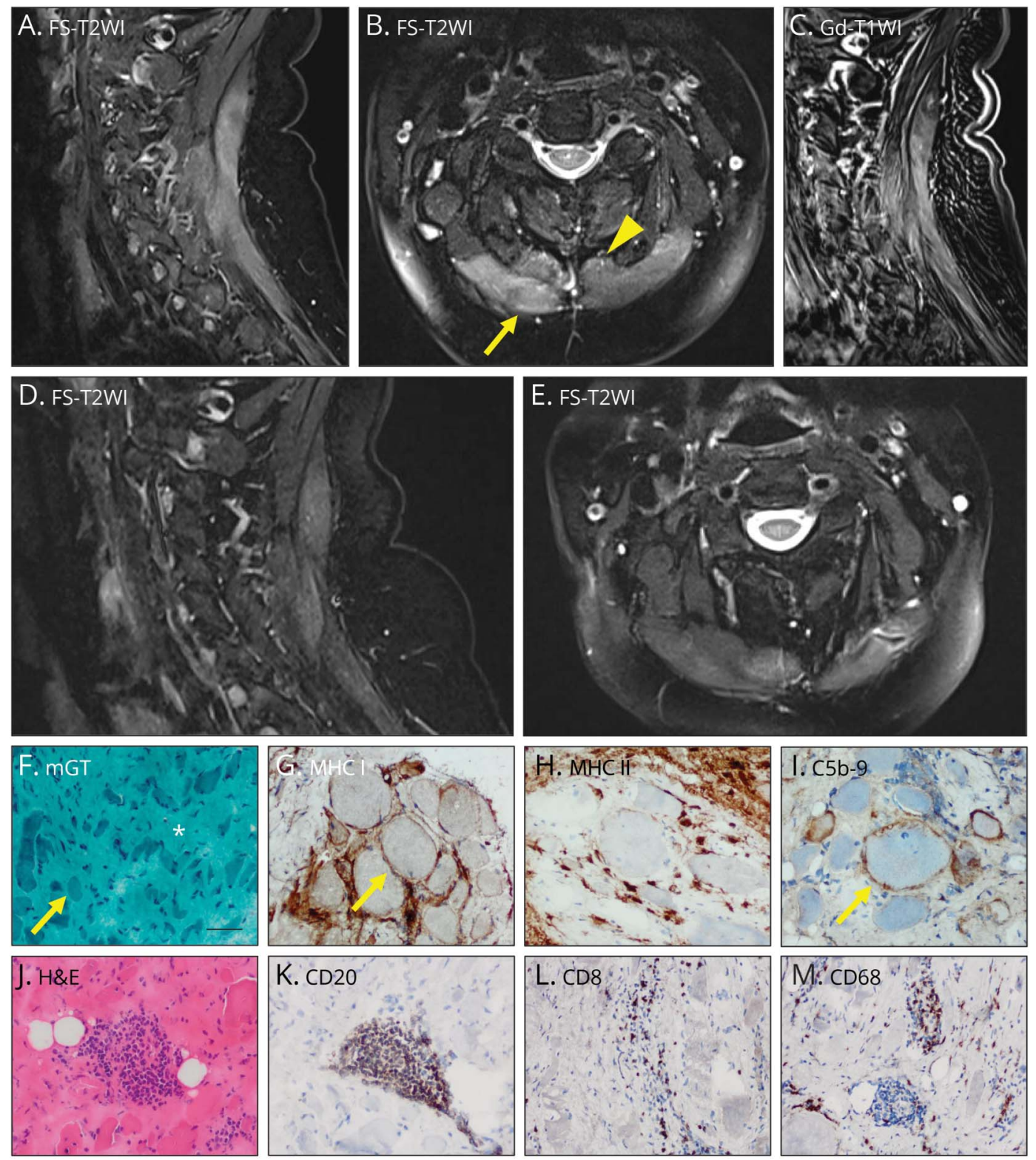

(A-E) 3 T MRI of the cervical spine. Upper row shows the initial status at presentation (A-C): marked bilateral muscular edema was observed in trapezius, splenius (arrow), and semispinalis (arrowhead) muscles in sagittal and axial fat-suppressed T2-weighted imaging (A and B: FS-T2WI). IV contrast administration shows vivid enhancement in the same region in sagittal subtracted T1-weighted imaging (C: Gd-T1WI). These findings are suggestive of inflammation of the muscles. Lower row shows improvement of the inflammatory change 7 weeks after initiation of corticosteroid treatment in sagittal and axial FS-T2WI (D and E). (F-M) Pathology of the biopsied semispinalis capitis muscle. Most fibers are atrophic, and marked endomysial fibrosis is present (F: modified Gömöri trichrome stain [mGT]. The arrow and the asterisk indicate a myofiber and fibrous tissue, respectively. Bar: $50 \mu \mathrm{m}$ ). Overexpression of major histocompatibility complex class I is observed on sarcolemma of many fibers (arrow), whereas major histocompatibility complex class II is not overexpressed on myofibers ( $\mathrm{G}$ and $\mathrm{H}$ : immunohistochemistry for major histocompatibility complex classes I and II [MHC I and II]). Myofibers showing C5b-9 complement deposition predominantly on sarcolemma of non-necrotic fibers (arrow) are scattered in $<3 \%$ of the total number of myofibers (I: immunohistochemistry for C5b-9 complements [membrane attack complex]). There are several clusters of mononuclear cells, which consist of predominantly CD20-positive cells (J: hematoxylin and eosin stain [H\&E]. K: immunohistochemistry for CD20). Focal infiltration of CD8-(L) or CD68-(M) positive cells are observed both in perimysium and endomysium, immunohistochemically. These staining results argue in favor of a B-cell mediated process, likely to interfere with the interferon-mediated pathways, accompanied by a solid T-cell response within the tissue as well. 


\section{Discussion}

This patient with advanced NSCLC had developed severe proximal and axial muscle weakness after ALK inhibition therapy, characteristically showing head drop. The agents included alectinib and crizotinib, but, considering the clinical course, alectinib was more likely responsible for the onset of symptoms. According to the reports of the Food and Drug Administration in the United States, severe (grade 3, based on the Common Terminology Criteria for Adverse Events) myalgia or musculoskeletal pain and CK elevation occurred in $1.2 \%$ and $4.6 \%$, respectively, of patients treated with alectinib. ${ }^{4}$ For crizotinib, there was no description of severe myalgia or any level of $\mathrm{CK}$ elevation. ${ }^{5} \mathrm{~A}$ report regarding sequential therapy with crizotinib followed by alectinib did not mention any muscular adverse event. ${ }^{3}$ Severe adverse muscular events causing obvious muscle weakness are rare, but still, the present case raises the possibility that ALK inhibitors, especially alectinib, can cause it. The etiology of the muscle weakness is inflammatory as shown by myopathological analysis and good response to corticosteroid therapy. It should be noted that the muscle affection was so responsive to corticosteroids that the patient could tolerate the cancer therapy and thereby kept her daily activity level. The clinical presentation of this case is partially similar to what has been described in myositis as an immune-related adverse event due to PD-1 immune checkpoint inhibitors (e.g., head drop and efficacy of corticosteroids). ${ }^{6,7}$ Increased fibrotic tissue was striking, which may be due to the nature of paraspinal muscles and enhanced by radiotherapy.

\section{Acknowledgment}

The authors thank Petra Matylewski and Silvia Stefaniak in the Department of Neuropathology, Charité-Universitätsmedizin for their excellent technical assistance.

\section{Study funding}

No targeted funding reported.

\section{Disclosure}

The authors report no disclosures relevant to the manuscript. Go to Neurology.org/NN for full disclosures.

\section{Publication history}

Received by Neurology: Neuroimmunology o Neuroinflammation February 3, 2020. Accepted in final form April 7, 2020.

\section{Appendix Authors}

\begin{tabular}{|c|c|c|}
\hline Name & Location & Contribution \\
\hline $\begin{array}{l}\text { Akinori } \\
\text { Uruha, MD, } \\
\text { PhD }\end{array}$ & $\begin{array}{l}\text { Charité-Universitätsmedizin, } \\
\text { Berlin, Germany }\end{array}$ & $\begin{array}{l}\text { Drafting and revising the } \\
\text { manuscript, study } \\
\text { concept and design, data } \\
\text { acquisition, analysis and } \\
\text { interpretation of data, } \\
\text { accepting responsibility } \\
\text { for conduct of research, } \\
\text { and final approval }\end{array}$ \\
\hline
\end{tabular}

Appendix (continued)

\begin{tabular}{lll}
\hline Name & Location & Contribution \\
\hline $\begin{array}{l}\text { Stefan } \\
\text { Kliesch, }\end{array}$ & $\begin{array}{l}\text { Carl-Thiem-Klinikum Cottbus, } \\
\text { MD }\end{array}$ & $\begin{array}{l}\text { Drafting and revising the } \\
\text { manuscript, data } \\
\text { acquisition, and analysis } \\
\text { and interpretation of data }\end{array}$ \\
\hline $\begin{array}{l}\text { Simone } \\
\text { Mchmid, }\end{array}$ & Charité-Universitätsmedizin, & $\begin{array}{l}\text { Revising the manuscript } \\
\text { for intellectual content, } \\
\text { data acquisition, and } \\
\text { analysis and } \\
\text { interpretation of data }\end{array}$ \\
\hline
\end{tabular}

Carsten Charité-Universitätsmedizin, Revising the manuscript
Dittmayer, Berlin, Germany for intellectual content, MD data acquisition, and analysis and interpretation of data

\begin{tabular}{|c|c|c|}
\hline $\begin{array}{l}\text { Hans- } \\
\text { Hilmar } \\
\text { Goebel, MD }\end{array}$ & $\begin{array}{l}\text { Charité-Universitätsmedizin, } \\
\text { Berlin, Germany; } \\
\text { Universitätsmedizin Mainz, } \\
\text { Germany }\end{array}$ & $\begin{array}{l}\text { Revising the manuscript } \\
\text { for intellectual content, } \\
\text { data acquisition, analysis } \\
\text { and interpretation of } \\
\text { data, and study } \\
\text { supervision }\end{array}$ \\
\hline $\begin{array}{l}\text { Alexander } \\
\text { Dressel, } \\
\text { MD }\end{array}$ & $\begin{array}{l}\text { Carl-Thiem-Klinikum Cottbus, } \\
\text { Germany }\end{array}$ & $\begin{array}{l}\text { Drafting and revising the } \\
\text { manuscript, study } \\
\text { concept and design, data } \\
\text { acquisition, analysis and } \\
\text { interpretation of data, } \\
\text { study supervision, } \\
\text { accepting responsibility } \\
\text { for conduct of } \\
\text { research, and final } \\
\text { approval }\end{array}$ \\
\hline $\begin{array}{l}\text { Werner } \\
\text { Stenzel, } \\
\text { MD }\end{array}$ & $\begin{array}{l}\text { Charité-Universitätsmedizin, } \\
\text { Berlin, Germany; Leibniz } \\
\text { Science Campus Chronic } \\
\text { Inflammation, Berlin, } \\
\text { Germany }\end{array}$ & $\begin{array}{l}\text { Drafting and revising the } \\
\text { manuscript, study concept } \\
\text { and design, } \\
\text { data acquisition, analysis } \\
\text { and interpretation of data, } \\
\text { study supervision, } \\
\text { accepting responsibility for } \\
\text { conduct of research, and } \\
\text { final approval }\end{array}$ \\
\hline $\begin{array}{l}\text { Robert } \\
\text { Handreka, } \\
\text { MD }\end{array}$ & $\begin{array}{l}\text { Carl-Thiem-Klinikum Cottbus, } \\
\text { Germany }\end{array}$ & $\begin{array}{l}\text { Drafting and revising the } \\
\text { manuscript, data } \\
\text { acquisition, analysis and } \\
\text { interpretation of data, } \\
\text { accepting responsibility } \\
\text { for conduct of } \\
\text { research, and final } \\
\text { approval }\end{array}$ \\
\hline
\end{tabular}

\section{References}

1. Peters S, Camidge DR, Shaw AT, et al. Alectinib versus crizotinib in untreated ALKpositive non-small-cell lung cancer. N Engl J Med 2017;377:829-838.

2. Hou H, Sun D, Liu K, et al. The safety and serious adverse events of approved ALK inhibitors in malignancies: a meta-analysis. Cancer Manag Res 2019;11:4109-4118.

3. Ito $\mathrm{K}$, Hataji $\mathrm{O}$, Kobayashi $\mathrm{H}$, et al. Sequential therapy with crizotinib and alectinib in ALK-rearranged non-small cell lung cancer- a multicenter retrospective study. J Thorac Oncol 2017;12:390-396.

4. U.S. Food and Drug Administration. Drugs@FDA: FDA-Approved Drugs. 208434Orig1s000. Alecensa/alectinib. Reference ID: 3859130. Available at: accessdata.fda.gov/drugsatfda_docs/nda/2015/208434Orig1s000SumR.pdf. Accessed January 30, 2020.

5. U.S. Food and Drug Administration. Drugs@FDA: FDA-Approved Drugs. 202570Orig1s000. XALKORI/crizotinib. Reference ID: 3007072. Available at: accessdata.fda.gov/drugsatfda_docs/nda/2011/202570Orig 1 s000SumR. pdf. Accessed January 30, 2020.

6. Touat M, Maisonobe T, Knauss S, et al. Immune checkpoint inhibitor-related myositis and myocarditis in patients with cancer. Neurology 2018;91:e985-e994.

7. Seki M, Uruha A, Ohnuki Y, et al. Inflammatory myopathy associated with PD-1 inhibitors. J Autoimmun 2019;100:105-113. 


\section{Neurology \\ Neuroimmunology \& Neuroinflammation}

Anaplastic lymphoma kinase inhibitor-associated myositis

Akinori Uruha, Stefan Kliesch, Simone Schmid, et al.

Neurol Neuroimmunol Neuroinflamm 2020;7;

DOI 10.1212/NXI.0000000000000735

This information is current as of May 6, 2020

\section{Updated Information \& Services}

References

Subspecialty Collections

Permissions \& Licensing

Reprints including high resolution figures, can be found at:

http://nn.neurology.org/content/7/4/e735.full.html

This article cites 5 articles, 0 of which you can access for free at: http://nn.neurology.org/content/7/4/e735.full.html\#\#ref-list-1

This article, along with others on similar topics, appears in the following collection(s):

Muscle disease

http://nn.neurology.org//cgi/collection/muscle_disease

Information about reproducing this article in parts (figures,tables) or in its entirety can be found online at:

http://nn.neurology.org/misc/about.xhtml\#permissions

Information about ordering reprints can be found online: http://nn.neurology.org/misc/addir.xhtml\#reprintsus

Neurol Neuroimmunol Neuroinflamm is an official journal of the American Academy of Neurology.

Published since April 2014, it is an open-access, online-only, continuous publication journal. Copyright

Copyright $\left({ }^{\circ} 2020\right.$ The Author(s). Published by Wolters Kluwer Health, Inc. on behalf of the American Academy of Neurology.. All rights reserved. Online ISSN: 2332-7812.

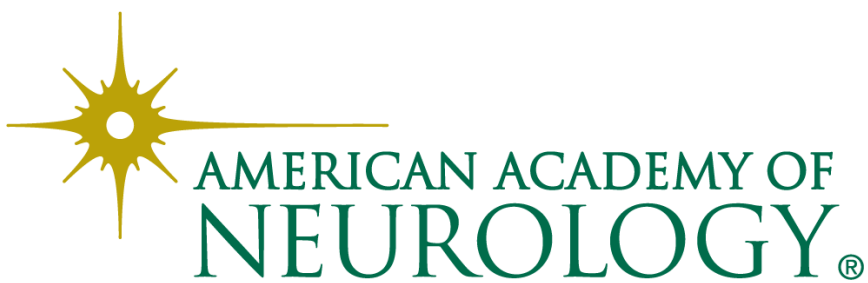

